\title{
Editorial - Processual Change in Taiwan
}

Actors, Values, and Change

\section{Stéphane Corcuff}

\section{(2) OpenEdition}

\section{Journals}

Electronic version

URL: http://journals.openedition.org/chinaperspectives/7290

DOI: 10.4000/chinaperspectives.7290

ISSN: 1996-4617

\section{Publisher}

Centre d'étude français sur la Chine contemporaine

\section{Printed version}

Date of publication: 1 June 2017

Number of pages: 3-6

ISSN: 2070-3449

\section{Electronic reference}

Stéphane Corcuff, «Editorial - Processual Change in Taiwan », China Perspectives [Online], 2017/2 |

2017, Online since 01 June 2017, connection on 24 September 2020. URL : http://

journals.openedition.org/chinaperspectives/7290 ; DOI : https://doi.org/10.4000/chinaperspectives. 7290

(c) All rights reserved 


\title{
Editorial - Processual Change
}

\section{in Taiwan}

\author{
Actors, Values, and Change
}

\section{STÉPHANE CORCUFF}

\section{Again, a new era in Taiwan}

T aiwan in early 2016 experienced a resounding change in political majorities. Not only was Tsai Ing-wen, President of the Democratic Progressive Party (DPP), elected to the presidency of Taiwan (the Republic of China), but also the Chinese Nationalist Party (Kuomintang, KMT) lost the majority it had held continuously since 1947 in the legislature. Less than two years before, in the late 2014 local elections, the KMT had already lost control of Taiwan's main local governments and assemblies. Among other factors, this series of defeats resulted from the marked popular dissatisfaction with the policies of President Ma Ying-jeou (2008-2016) for most of his two terms in office. Mr. Ma, of the KMT, engaged the island in closer cooperation with China, which did not produce the economic benefits he had hoped for in exchange for a conciliatory posture vis-à-vis China, whose irredentism over Taiwan irritates most Taiwanese. (1)

If a new majority in the legislature or a change in executive power can undoubtedly be considered as changes in themselves, change, as a notion, can be studied as a complex process going beyond party change and its most obvious results, the adoption of new laws and new policies. The process of change, whether rapid or slow, visible or invisible, sudden or progressive, is often pushed by actors with agendas based on worldviews and legitimized by values. As Gérard Wormser, a French political and moral philosopher, recently put it, "An election is the occasion to revise the social pact." (2) In this sense, political change should be studied in connection with the pressure exerted by various organisations structuring civil society through political institutions in representative democracy: the legislature, government and administration, the presidency, and sometimes even the judiciary.

The January 2016 election, ending in victory for the Taiwan nativist parties opposed to unification with China, gave the latter an absolute legislative majority. They wasted no time in ushering in a series of new laws and policies, some announced before the first meeting of the house in February, and others detailed by the president in her inauguration speech in May. Among others, we can notice an official apology to Taiwan's Aborigines; ${ }^{(3)}$ the launch of a "New South Policy" (xin xiangnan zhengce) to circumvent economic dependency on China; ${ }^{(4)}$ the reopening of a policy of transitional justice, now focusing on the immense ill-gotten wealth acquired by the KMT during decades of dictatorship; ${ }^{(5)}$ the gradual scrapping of unjustified and costly benefits granted to civil servants, occupations most often chosen by Taiwan's Mainlanders; ${ }^{(6)}$ the reform of weekly work hours to reduce working time while enhancing productivity; ${ }^{(7)}$ or the proposal, still under discussion, of a multi-billion dollar "Forward-looking Infrastructure Development Program." (8)

\section{Civil society and the multiplicity of actors in democratisation}

These efforts to combine social justice, transitional justice, economic dynamism, and the unlocking of the island's geopolitical deadlock have launched Taiwan on a path of rapid reform. But how do we evaluate such changes? And what does change mean? The changes briefly described above

1. This special issue originated in two workshops organised in Nottingham and Taipei by the Taiwan Study Programme of the University of Nottingham and the Taipei branch of CEFC at Academia Sinica: The Ordinary and Extraordinary in Taiwan and Political, Social and Economic Change in Taiwan, and in a subsequent call for papers on "Processual change in Taiwan." The papers were selected and edited by Lee Chun-Yi and myself. I warmly thank my colleague Chun-Yi, together with colleagues of the editorial board of China Perspectives, for their invaluable help in the long process of editing a new special issue on Taiwan.

2. "Une élection est l'occasion de réviser le pacte social." Gérard Wormser, "La grande transformation. L'élection présidentielle française de 2017" (The great transformation. The French presidential election in 2017), http://sens-public.org/article1250.html?lang=fr (accessed on 7 May 2017).

3. Apologies for centuries of acculturation, deprivation of land, and ethno-cultural bias after Formosa started to be colonised by Han people in the seventeenth century. The Presidential Office announced by the same token the resumption of mapping, initiated under the previous DPP administration (of President Chen Shuibian, 2000-2008), of Aboriginal "traditional" territories; it added explicitly the aim of ultimately reaching a form of devolution of political and administrative power to Aborigines in those territories. On the adoption of a law regarding the protection of Aboriginal languages and the challenge it will meet in its application, please see elements of a seminar held at CEFC Taipei on 26 May 2017: http://www.cefc.com.hk/fr/event/taiwans-policy-regarding-indigenous-peoples/.

4. See the article by Lin and Lee in this issue. This dependence is considered a national threat and a top geopolitical concern. The new policy will foster economic, political, social, and cultural exchanges with Southeast Asian nations. On the New South Policy, see the analysis by Bloomberg Politics: https://www.bloomberg.com/politics/articles/2017-05-16/taiwan-seeks-stronger-asiaties-to-overcome-reliance-on-china (accessed on 17 May 2017).

5. The Taiwan-born, pro-democracy President Lee Teng-hui (1988-2000) directed a smooth transition from dictatorship to democracy. When initially launching the policy of transitional justice, he focused essentially on recognising the political crimes of his party (lifting the taboo on the 1947 massacre by the KMT and recognising the victims of the following period of White Terror (see Stolojan in this issue).

6. It notably targeted the extremely generous pensions given to civil servants (such as teachers, bureaucrats, and military personnel, the so called jun-gong-jiao electoral iron base of the KMT) in a country where pension funds are threatened with bankruptcy, and the extraordinary $18 \%$ interest rates on their savings, which no other Taiwanese could enjoy.

7. This is supposed to be achieved by reducing some national holidays and protecting employees' rights to a minimum number of resting days per week, while taking into consideration the considerable variety of situations, depending on the nature of the business.

8. Yet to be voted on by the Legislative Yuan at the time of writing, this policy combining support to the economy with public spending, development of infrastructure and transportation, modernisation of the economy, and urban renewal, is projecting expenses of US\$29.15 billion ( $€ 26$ billion) over eight years. 
are seen only through what may appear, at first glance, to be their main political and administrative actors: the presidency, the administration, and the legislature. Such is the view of institutionalism, and this type of analysis forgets what is perhaps the biggest part of the picture: the multitude of actors within the state apparatus, next to it, and engaged in cooperation with it, or outside of it and in opposition to, if not in conflict with it, that all played a role in the ultimate adoption of new policies.

It is all the more important to remember that civil society actors have proved very active since Taiwan's democratisation period. Already involved in accelerating Taiwan's early democratisation in the 1980s and 1990s, the island's civil society activism was particularly notable under the presidency of Ma Ying-jeou against the backdrop of concerns raised on a regular basis regarding respect for the independence of judges, protection of the neutrality and independence of the media, the social negotiation of delicate issues such as land redevelopment and urban rezoning, and compromises with the symbols of national sovereignty when negotiating with China, among others.

These and other factors led to the occupation of Taiwan's parliament in 2014, initially by students, and then with the help of numerous civil society organisations and the general public, for three weeks (18 March - 10 April). The occupation was one of the most successful in the series of Occupy movements in the world: it forced China, the KMT government, and President $\mathrm{Ma}$ to suspend a dubious trade agreement negotiated with no transparency and with no proper mechanism of legislative supervision and ratification. Since then, until the end of Ma's presidency and ever since, no significant negotiation has taken place between the two sides of the Taiwan Strait. Interactions between civil society and the state apparatus can prompt changes that sometimes run radically opposed to the government's agenda, without the need for power change or revolution.

\section{Actors and values in processual change}

What is processual change? It can be understood as the process by which different actors promote change to enhance the conformity of society (or the economy, the polity, the arts and culture, public values, or any other dimension of human, animal, or natural life) to their values. Each promotes, in a way, an alternative world, inasmuch as they want to see the existing situation change.

This is based on a specific worldview shaped by their values. Values here are to be understood with no relation to any conception of morality, with neither positive nor negative connotations attributed to them by the analyst. Values here are what actors deem worthy of fighting for, for themselves and most importantly for others. The scope of the desired change can be limited to a specific category of the population (promoting gender equality, rights of migrants, or same-sex marriage, etc.), or be extended to the whole population, whether of humans, animals, or even plants: fighting against abortion, defending animal rights, promoting renewable energy, transparent governance, or a free press, abolition of the death penalty throughout the world, or the denuclearisation of the planet, etc.

\section{Actors, values, and change: The use of social media in the Sunflower Movement}

The occupation of Taiwan's Parliament in 2014 is a case in point. The Sunflower Movement unfolded in a context of deepening anxiety among Tai- wan-identified civic groups and militants over China's growing influence in the world and Taiwan, especially under Ma Ying-jeou. It was also nurtured by disillusionment with a representative democracy continuously constrained by the KMT's eternal legislative majority. It led interest groups, civic associations, and the techno-savvy younger generation of a highly technologised society that had rapidly embraced new information and communication technologies (NICTs) to an unprecedented mobilisation that halted most government projects at once and for the rest of Ma's second mandate. This movement revealed a techno-based empowerment movement in the process of maturation in post-martial law civil society in Taiwan, with new actors and new values at the centre of the process.

Mobilisation through NICTs in popular protests has often been observed in recent popular revolts or Occupy movements in the world. Yet the role of NICTs in events leading to movements, as well as in the unfolding of the movements themselves, has often been neglected. Beyond being a tool of initial mobilisation, NICTs enable and greatly facilitate various phenomena, such as processes of group construction (through information and intersubjectival construction); collective management of fear (of repression, of parental rejection, of unknown possible legal consequences, etc.); and re/empowerment of the self, to define what kind of militants activists are, what kind of society they want, and how they should make it happen.

The use of NICTs is old news in Taiwan, ${ }^{(9)}$ a country with one of the world's highest penetration rates for social media. For instance, Taiwan's most famous Bulletin Board System, the PTT, Facebook ( $90.9 \%$ penetration), and Line (over $80 \%$ penetration) are used daily, sometimes all day long, for multiple purposes (general information, common interest groups, advertising and professional opportunities, emotional life, etc.), and across generations. ${ }^{(10)}$ Taiwan is also a country where the convergence between civic activism and computer technologies, encapsulated in the expression "civic tech," is dynamic and promising. This convergence was early symbolised by the launch of an important civic tech initiative, preceding the Sunflower Movement by two years: the gØv galaxy. Launched in October 2012 and structured by the platform www.g0v.tw, gØv gives free and simple access by and to netizens to full and serious information and assessment of central and local governance in Taiwan, but is also a galaxy of hundreds of shared projects related to civic activism - we have here a characterisation of one of the core new actors of the movement, and of its values. $g \varnothing v$ posits itself as an alternative to erratic, incomplete, complex, erroneous, or malicious information by administrations and its digestion and manipulation by traditional media or spin-doctors, but also as a tool of civic empowerment. As a radically new actor, $g \varnothing v$ has become one of the biggest projects of its type in the world, and one of the earliest. With its Global Summits, where civic initiatives have proliferated and where activists from many countries have connected since 2014, Taiwan has posited herself as one of the world's beacons of civic tech and an actor in the increasingly connected technosphere reaching its global stage.

It is no surprise, in such a context, that social networks and the latest ICTs have been used to launch and manage the 2014 civic movement with re-

9. Its earliest public form is the famous PTT, a Bulletin Board System (BBS) created in 1995, at a time when Internet and email were still only known to a few in the world. Created 18 years before the Sunflower Movement, PTT, still in use, remains as successful as ever, even as its interface has become terribly vintage.

10. Taiwan Institute for Information Industry (Caituan faren zixun gongye cejinhui) is at the time of writing working on a report on the use of NICTs in Taiwan, with a pre-report published on 1 May 2017: http://www.iii.org.tw/Press/NewsDtl.aspx?nsp_sqno=1934\&fm_sqno $=14$ (accessed on 12 May 2017). 
markable operational success. Analysing their use in this civic movement reveals the emergence of a generation of new actors advancing values such as administrative transparency, Taiwanese identity, legislative overview of government negotiations with China, protection of the island's sovereignty, fair treatment of information by the media, etc., through public debate enabled by these new tools. Interestingly, the debates facilitated by the intensive use of ICTs made it possible for a wide variety of other issues to be progressively added to the initial questions discussed by the Sunflower Movement:Taiwan's economy, social justice, gender equality, same sex marriage, the nuclear plants, etc.

As the use of NICTs has been manifold, a typology is needed. At least seven types of usage can be observed: rallying and mobilising around the Parliament to express opposition to KMT politics and achieve a critical mass to secure the survival of the movement; protecting students and demonstrators by occupying public space around the legislative chamber; organising the movement logistically - getting help, food, water, phone chargers, blankets, and all the items needed for a lasting occupation; debating political, economic, societal, and geopolitical issues; launching projects such as impeachment of elected officials; crowd-funding for purchasing goods and advertisements; and informing the world by producing an autonomous discourse and denouncing "unfair media treatment," truncated information, biased reporting, or the propagation of false information by media outlets that, in Taiwan, are free, but have a strong tendency to reflect political bias.

In doing so, the whole spectrum of current social media and NICTs has been mobilised. Facebook was massively used to inform, mobilise, and organise, just as the PTT bulletin board was critical as a platform where instructions could be sent to everyone. Instant message providers such as Line, WhatsApp, Messenger, Instagram, etc., were helpful in communicating with specific persons or within ad hoc groups. Firechat, another tool for instant messages, does not require $3 \mathrm{G}$ or $4 \mathrm{G}$ for its connection and hence links telephones through Bluetooth on a local scale, which was useful in saturated networks for informing others of a position or any important information such as perceived danger or a new event such as civic courses by university professors supporting the movement and teaching onsite. Google Docs, gØv.tw, Line, and Reddit have all been used to propose projects, mediatise the movement (with streaming broadcasts, online Q\&A sessions, online publication of press-feeds, and transcripts of interventions by student leaders), and discuss issues debated during the movement. YouTube has been mobilised to circulate short videos with transcripts in a vast number of languages, including Turkish, Russian, Arabic, French, Japanese, etc. Flying' $\mathrm{V}$, ZecZec, and vDemocracy, all platforms of crowdfunding, have been used or created to fund the movement and its costly advertisements, such as the series "Democracy at 4 AM," while Hackpad provided a slide-share system to centralise, synchronise, and publish online PowerPoints explaining the organisation of the movement and what volunteers could do, where to go, and where to ask questions. This is just a glimpse of the digital sophistication of a movement occupying physical space at the same time.

A number of new actors emerged or had their existence revealed or confirmed by the movement: student leaders with precise knowledge of complex issues pertaining to Taiwan's economy or society; newly formed groups advocating social progress or Taiwanese independence, and composed of a younger generation of activists who will increasingly replace the now elderly first generation of Formosan nationalists; or new politicians or politiciansto-be, coming from academic or cultural careers. All placed themselves ex- plicitly outside traditional parties, including the one most inclined to support their ideas, the DPP, with which they officially maintained a respectful distance. In this process, a new and potentially extremely powerful actor may have emerged unnoticed: the collective intelligence composed of thousands of interconnected activists.

\section{Cases studied in this special issue}

Processual Change in Taiwan discusses four case studies analysing as I did above the role played by actors in processes of change in Taiwan: the definition of the contested nation in tourist souvenirs by private operators addressing tourists' needs (Adina Zemanek), how netizens have tried to prevent policies by local governments regarding the invention of a cultural tradition with which they did not identify (Fiorella Bourgeois), the question of transitional justice and how the authoritarian past is discussed today in Taiwan by a variety of actors such as victims, associations, and the state (Vladimir Stolojan), and how a powerful business magnate and civil society militants confronted each other over the question of media independence in a context of China's growing influence over Taiwan under the Presidency of $\mathrm{Ma}$ (Lin and Lee).

In her article, Adina Zemanek looks at present-day tourist souvenirs that are shaping the perception of Taiwan's national identity by representing it graphically as an individual entity, separate from China. Zemanek shows how designers of postcards, stickers, and other souvenirs capture Taiwan's specific history, geography, and daily life to generate a notion of community. While public diplomacy may have depicted Taiwan, in the recent past, as the preserver of traditional Chinese culture, placing it in China's shadow, the actors discussed in this article put forward Taiwan's everyday sights and unique arrangement of local foundations and outside influences that have shaped its history. It is time, the author argues, to have a close look at these cultural productions. By endorsing these diverse heritages, including Japanese influences, which were usually eschewed by official discourse in the past, they contribute to establishing historical continuity and memorial coherence. The decisions over branding Taiwanese identity in these souvenirs are taken by grassroots agents, and they reflect their internalisation of Taiwanese identity.

Fiorella Bourgeois' article shows again that any change is multidimensional. The question addressed here is the destruction of two Hakka kilns dating back to the mid-twentieth century and the construction of typical Hakka village houses (tulou) that are found in China but not in Taiwan. The article analyses the emergence of voices from civil society, in some cases possibly expressed online for the very first time. Through social media, individual voices coalesce into a form of public collective voice, quite possibly with no organisation behind them. They disrupt the usually too-easy process of decision-making by elected local officials unused to being challenged by electors, especially through NITCs. Actors are here clearly identified and posed face-to-face (netizens against officials), while the underlying values are once again administrative transparency, adequate spending, protection of Taiwan's identity, and citizen watch.

A third article, written by Vladimir Stolojan, analyses social memory, another kind of collective discourse elaborated and maintained at the level of the individual. The history of transitional justice in Taiwan starts with the lifting of martial law in 1987, with the constitution of associations of former political prisoners, and the movement calling for the rehabilitation of the victims of the February 28 massacre - the 1947 massacre of the Taiwanese 
elite and militants opposing the KMT's nepotism and incompetence. They obtained acknowledgment of the massacre and financial compensation in a movement that later extended to the subsequent White Terror and its victims. Stolojan points out the length of the road of transitional justice: the adoption of a legal framework dealing with the tragedy of the victims was not the end of their fight, as they had to wait several more years to see their voices more deeply acknowledged in Taiwanese society and the state to better understand the meaning of their request and later modify the institutional discourse in museums. Change is here gradual, in a negotiated process between associations of victims, the state apparatus, and the collective memory of the Taiwanese populace.

The last article, written by Lin Lihyun and Lee Chun-Yi, introduces transboundary actors in the form of a businessman who earned a fortune in China and came back to Taiwan with the intention of purchasing media outlets and influencing Taiwanese to look more positively at China - with the expectation that his efforts would be appreciated in China and allow further development of his businesses there. The authors examine the relations between emerging media capital and the Taiwanese government in the context of a growing "China factor." Although the model of "patron-client relationship" is useful to describe the relationship between the government and the media within one nation-state, in the case of cross-border capital flow, business groups may be involved in rent-seeking activities in different countries and have to deal with different and even rival governments. In the case of China-Taiwan relations, economic activities across the Strait have always been entangled with political intentions. The article presents the case of Taiwan's Want Want group, which gained immense interests in China and strong ties with the Beijing government after entering the Chinese market as early as the 1980s. It was not until 2008 that Want Want returned to Taiwan to purchase a media outlet. With its major business interests in China, Want Want openly supported the official ideology of the Chinese Communist Party, and its attempts to ignore the legal framework and political values of Taiwanese society provoked fierce debate between the conglomerate, the state, and civil society radically opposed to the deal.

\section{Conclusion}

Actors establish agendas for themselves and for society along the lines of changes they are determined to fight for. If it is relatively easy to discribe changes from an institutional point of view (for instance, which law was amended by a legislature, with which consequences), it is more complicated to analyse changes when we focus on the process and not on the result. In each case study above, whether a businessman, civic tech groups, private publishing companies, the state, elected officials, China, victims of political persecution, or local residents in Taiwan, competing actors, old and new, as well as the values they defend and the channel of influence they use, are analysed to show how change is envisioned, programmed, and engineered. Changes studied here are actively engineered either by competition, conflict, or cooperation among actors in ever-changing situations.

The weakness of civil society is a consequence and a sign of dictatorship, while totalitarian political structures try to eradicate it in their attempt to establish a direct link between the Party and every citizen and to avoid the emergence of intermediary bodies they do not control. Conversely, it is difficult to imagine a democratisation process without the incremental constitution of a civil society. Whether analysing Chinese or Taiwanese social or political transformation, focusing on actors and their values can be a way of revealing the multiplicity of stakeholders to be identified and studied in order to understand more comprehensively the processes of elaboration or reinforcement of such a civil society.

Projects currently being turned into laws by the legislature and into policies by the executive branch of government in Taiwan will likely lead to important changes at both the practical and symbolic levels. They have been widely discussed for years by civil society, the upsurge of which during the 2014 Sunflower Movement further destabilised the KMT and helped bring the opposition to power in 2016. Yet, after the inauguration of a new government and a new legislature endorsing most of these reforms, each reform or project still met with resistance, debate, and sometimes new protest in the streets of Taipei. This course of events illustrates the vitality of Taiwanese civil society, even though, unlike the large popular protests of the Ma Ying-jeou era, recent protests appear sectional - in other words, led by those who directly have something to lose in reforms - rather than pulling in all of society as the Sunflower Movement did in March-April 2014.

\section{IStéphane Corcuff is Director of the CEFC Taipei}

(scorcuff@cefc.com.hk). 